\title{
THE CONCEPT OF HUMAN ABILITY (QUDRATUL INSAN) IN ISLAMIC EDUCATION PROCESS
}

\author{
Dadan Nurulhaq \\ UIN Sunan Gunung Djati Bandung \\ Email:dadannh@uinsgd.ac.id
}

\begin{abstract}
:
This study aims to examine the concept of human ability (Qufratul Insan) in the process of Islamic education. The approach used is qualitative, namely research on the condition of natural objects, where researchers as a key instrument. The data collection technique is done by triangulation (combined), data analysis is inductive, and the results of the study emphasize the meaning rather than generalization. The results of the discussion showed that the human potential given by Allah SWT in the form of vision, hearing, and heart that all three have a relationship where hearing functions to maintain knowledge that has been found from the results of learning and learning, vision functions to develop knowledge and add research results by conducting further studies. The heart is in charge of cleansing knowledge of all bad qualities.)
\end{abstract}

Keywords: Concept; Human Ability; Islamic education

\section{A. INTRODUCTION}

Salah satu persoalan pokok yang perlu diketahui tentang manusia sebagai peserta didik ialah sifat-nature (innate) possessed by humans when he was born. One of the main problems that need to be known about humans as students is the basic characteristics (innate) that humans have when they are born. Educational experts agree that theory in education is greatly influenced and determined by views of human nature. This view or conception of human nature is the starting point of the theory and implementation of education. It determines whether education is needed or not, whether education is useful or not. If necessary, what aspects need to be developed in education and how to do it (Abdul Basyit, 2017).

According to Islam, man is the most perfect creature, he was created to be a kholifah on earth, when a human being is born he carries the abilities called fitrah, this nature is called potential. Therefore, in relation to education, the existence of nature is very well known in Islam. Humans in the Koran are creatures born in a holy state of education that can change and determine human beings to become concrete humans (Kosim \& Syah, 2016. p. 63-97).

However, the reality that is faced is that humans still do not have full awareness of their potential as well as their life goals that hold the mandate as caliph on this earth. Human behavior today that leads to more widespread moral decadence, social problems such as corruption cases, illegal logging that causes damage resulting in floods, landslides and so on. Poverty is increasingly rampant due to a lack of concern for others, resulting in many deaths due to hunger, as well as many conflicts due to differences in various things that lead to violence and bloodshed (Permatasari, 2009. p. 3).

As servants of Allah, humans are obliged to worship Allah, in the sense of always submitting and obeying His commands to enforce and know Him according to the instructions they have given. Worship contains two definitions, namely a special meaning and a general meaning. In a special sense, worship is carrying out the rules governing the relationship between the servant and his Lord whose procedures are detailed in 
the Qur'an and Sunnah, while worship in a broad sense is an activity whose starting point is sincere and is aimed at achieving pleased Allah in the form of righteous deeds (Mualimin, 2017. p. 249-266).

From a theological perspective, Islamic education must be based on the teachings of al-Qur'an and alHadith which have the core of tauhid. Tawhid in this position occupies the core which is fundamental and is the basic value of Islamic education. Tawhid is the belief of a Muslim which is manifested in the following matters: (a) Tauhîd Ulûhîyah, is a belief that Allah is the only substance worthy of worship and the only source of values, teachings and life. The implication of such a belief is that Islamic education must be intended (planned), implemented and evaluated in the framework of worshiping (worshiping) Allah (Mohammad Muchlis, 2007. p. 236-249).

So the problem now is, what are the criteria for humans to become the goals of education? Of course the answer to this question returns to the philosophy of life of each. This means that the perspective on what and who humans are will usually give birth to treatments that gradually transform into a policy (system) as an operational guide in realizing existing ideals. From this the formation of a framework or form of education between nations, groups, religions and others. Especially if you look at the current fact that there is coexistence between nations and other nations, between groups and other groups, the differences in the implementation of education are getting sharper. Paradox has become a phenomenon in life in public spaces because there is no uniform philosophy of life which will also affect the implementation of education. Like it or not, it must be understood as part of the plurality of mankind (Harahap \& Siregar, 2017. p. 148-163). The purpose of this study is to examine how the concept of ability (Qudrotul Insan) in the process of Islamic education.

\section{B. METHOD}

The approach used in this research is a qualitative research approach, because the study to be discussed is the concept of ability (Qudrotul Insan) in the process of Islamic education. The qualitative approach itself is a research on the condition of natural objects, where the researcher is the key instrument. The data collection technique is done by triangulation (combined), data analysis is inductive, and the results of the research emphasize meaning rather than generalization.

\section{RESULTS AND DISCUSSION}

\section{Human Nature}

From the point of view of anthropology, the philosophy of human essence (essence) is investigated through three steps, namely: the first step, discussion of human etymology which in English is called man (the origin of the word Anglo Saxon, man). The second step, discussing the essence of man with the indication that he is a creature on earth like all earthly objects, except that he appears on earth to pursue a higher world. The third step, the universal development of the tendencies of human nature will eventually lead to the sublime humanity declared by humanism as the goal of mankind, which is the subject of a historical process in the process of developing human material and spiritual culture on earth. (Syamsul Rizal, 2017. p. 87).

Meanwhile, human nature in Islam can be explained as follows. First, humans are the best creatures. Humans are the creation of Allah SWT which is good (beautiful, the best) in the form of its occurrence among creatures in this universe so that it is called the Al-quran surah al-Tiin (85) with human ahsani taqwiim and but can also fall to asfala saafiliin. Ahsani taqwiim in the sense that humans have a higher rank 
physically and spiritually when compared to other creatures. From a physical point of view, the advantages and perfection of humans lie in the form of physical creation and the appearance of their faces which are very beautiful and perfect, plus the position of their bodies that is straight up. And from a spiritual perspective, humans are beings with religious culture and spiritual power, because humans have the ability of reason and heart that are not shared by other creatures. Ahsani taqwiin also means people who are faithful and pious and clever to give thanks to Allah SWT. Second, humans as the most perfect creatures (insan kamil). Humans in Islam are also known as insan kamil with their physical, intellect, heart, morals, social and artistic potentials as well as their psychological, psychological potential. Third, humans as caliphs on earth. The existence of humans on earth is to function as a caliph whose task is to prosper its inhabitants. Therefore, all psychological forms and mental health on earth must be in accordance with what Allah has taught. Fourth, humans are the best creatures in the process of occurrence. Fifth, beings that are Divine (spiritual) (Amir, 2012. p. 188).

In the Koran, there are several terms used to describe humans, namely; al-basyar, an-nas, al-insan, dan bani Adam. The term is based on the differences between humans and other creatures of Allah in terms of form, as well as the potentials bestowed on humans, such as the mind, heart and also the lust that is useful for studying and understanding the universe. (Fhauziah, 2015. p. 42).

Human in concept al- Basyr, seen from a biological approach. As a biological being, a human being consists of material elements, so that he displays a figure in a material physical form, namely in the form of a gross body. Al-Basyr in language is human physical. Alquran uses this word 36 times with different emphases. Apart from being used to describe the human side of the Prophet and Prophet, such as eating, drinking, etc., it is also used in themes such as the process of human creation, humans as humans in general, human skin, and humans all die. So it can be understood that humans are one of the biological creatures that have physical, meaning that there are general symptoms inherent in the physical so that humans are very dependent on their natural nature. (Harahap \& Siregar, 2017).

Al-Insan formed from the root word Nasiya ( يسن (يسن ) Nisyu ) which means forget, from the word Insu ( ( سنا it means happy, tame, harmonious, and there is also a root word Naus ( سئن ) which implies "movement or dynamism". Referring to the origin of the word al-Insan, we can understand that every human being basically has a positive potential to grow and develop physically and mentally and spiritually. In addition, humans are also provided with a number of other potentials, which have the opportunity to propel themselves towards negative and detrimental actions, attitudes, and behaviors (Mualimin, 2017).

Word Bani ( ) derived from the word ban ā ( ع ) it means building, building, establishing, composing. So Bani Adam means the lineage of the descendants of the children of Prophet Adam and subsequent generations. From the very beginning of the presence of Adam's (human) children and grandchildren like animals on this earth, only humans who reached the Adam stage were able to bear responsibility. "Some thinkers say, it is humans who are civilized, while jinn are uncivilized creatures. But this human also has levels. Humans who have reached the level of Adam, are still continuing and will end up in a higher condition than Adam (Abdullah, 2017. p. 331-344).

Meanwhile, the word al-Nas (سانL) repeated 240 times. The term "al-nas" generally describes a neutral universal human without any traits. Certain properties that limit or color its existence, while the word "insan" generally describes a human being with various potentials and characteristics, the meanings of the above root words at least provide a cursory description of the potential or nature of the creature, namely that it has the nature of forgetfulness, the ability to move that gives birth to dynamics. He is also a being who always or naturally gives birth to a sense of joy, harmony and happiness to others (Imam Faqih, 2005. p. 50-68). 
From some of the terms above, it can be combined that humans are God's creation as descendants of Adam who have a clear form, are able to speak and think and live in a social community.

\section{Human Potential According to Al-Qur'an}

Muslim leaders view human beings as being endowed with a unique ability, with this ability, all humans can recognize God as God, and recognize His commands as norms or necessities. Innate knowledge and obedience to God are natural, while iniquity is not natural. (Rahmawati, 2008).

One of the verses of the al-Qur'an which discusses human abilities is listed in surah an-Nahl verse 76 , as follows:

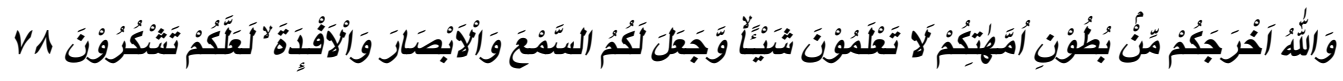

And Allah took you out of your mother's stomach knowing nothing, and He gave you hearing, sight, and conscience, so that you may be grateful.

When humans are born, they do not have a single knowledge and become weak creatures, so that in their development humans are given the ability to hear and see Allah so that humans have knowledge and with their knowledge humans give thanks to Allah (Hartono, 2013. p. 311-326).

The verse above implies that there are three potentials involved in the learning process, namely; al-sam'a, al-abshar and al-af'idah. Lexically, the word al-sam'a means the ear whose function is to pick up sound, understand speech, and so on. Al-Asma 'is a singular form because what is heard is always the same, either by one person or many people and from any direction the sound comes (Rahardjo, 2016. p. 1411-29).

Ibn Katsir in his interpretation states that Allah SWT has given the grace that He bestows on His servants when they are removed from their mother's stomach in a state of not knowing anything. Then it provides hearing by which they know sound, the vision by which they can see various things, and the mind which is the center of the heart. Then the mind by which humans are able to distinguish various things that bring harm and bring benefits (Katsir, 2004. p. 83).

Muhaimin revealed that the above verse explains the state of a human child who comes out of the mother's womb in a weak state and doesn't know anything. Then Allah SWT bestowed the potential in the form of hearing, sight and heart. These potential tools are awarded by Allah SWT to humans in order to gain knowledge (Akhirin, 2015).

The same opinion was expressed by Quraish Shihab regarding the above verse, Allah brought a human from the mother's stomach from what was originally not being into being, from not knowing to being knowing. With hearing, sight, and various hearts as provisions for gaining knowledge in order to be grateful by using these tools in accordance with the purpose of Allah to bestow it on humans (M. Quraish Shihab, 2005).

These potentials should be appreciated and recognized as a mandate from God Almighty who will be held accountable before Him. These potentials can develop naturally if humans get educational assistance. In a hadith of the Prophet SAW. It is stated that "Every baby who is born in a natural state or clean, the environment outside the baby will give color or influence to the black and white hue of the baby's life 
journey". The same thing was expressed by a John Locke with the Tabularasa theory that a child who is born into the world is like white paper that has not been written with ink in any color (Siregar, 2016. p. 100109).

The core of QS. An-Nahl: 78 above provides an explanation that humans will epistemologically build their knowledge by hearing, seeing, and their heart. Allah gave these three potential tools to humans with the aim of turning them from not knowing to knowing (having knowledge). After humans have knowledge of knowledge, humans become grateful.

Education is basically an activity to seek knowledge. Allah SWT through the Prophet Muhammad SAW ordered humans to study, even to study compulsory knowledge. QS. an-Nahl: 78 explains to Muslims about the way humans seek knowledge. This verse is very worthy of being used as a philosophical basis for developing the concept of human capabilities in the process of Islamic education.

\section{Concept of Human Ability in Islamic Education Process}

In the framework of Islamic education, the perfection of human physical and spiritual functions must be based on Islamic values, namely values derived from the Al Quran and Hadith. In relation to Islamic education, Moh. Fadhil Al-Djamali argues that Islamic education is a process that directs humans to a good life. And raise the degree of humanity in accordance with basic abilities (fitrah) and teaching abilities (influence from outside) (Permatasari, 2009).

As a servant of Allah, Islamic education is carried out to provide correct knowledge, understanding, and practice in carrying out Islamic teachings an emotional spiritual need. At the practical level, learning Islam by using this approach emphasizes the learning of true beliefs / beliefs ('aqîdah), practicing istiqâmah (syarî'ah) and the refraction of Islamic moral ethics (akhlâq).

Effectively, Islamic education is able to guide and develop all potential, both physical and spiritual potential. In the process of Islamic education, humans are given the ability to shape their personality, transfer their culture from one community to another, know the good and bad values of things, and so on. The implications of human free will have involved the educational process. Education becomes a point of concern with a source of assistance to students evaluating alternatives and selecting good and bad. Education is not seen as a process of coercion from an educator to determine every step that must be accepted by their students individually. So guidance is a compulation that the main characteristics of education must pay attention to this freedom (Abdul Basyit, 2017).

According to Abdurrahman An-Nahlawi, education must have the same goals as the goal of human creation. The conception of the universe clarifies the basic purpose of human existence on this earth, namely servitude, submission to Allah, and his caliphate in advance this will keep people from exploiting nature. There is only the attitude of prospering the universe through the manifestation of obedience to Allah's law (Akhirin, 2015).

Arifin explained that psychologically, the human potentials that must be developed in Islamic education are: (1) Basic potential which is the basic ability of humans that is dynamic and develops actively, (2) Talent and intelligence in the form of cognitive abilities, power and emotion. By developing this ability humans become experts and professionals in their fields, (3) Instink (ghârizah), the ability to act, (4) Intuition, the psychological ability of humans to make contact with God, (5) Character, namely the psychological ability to have morals and ethics in their interactions with fellow humans. This character is closely related to a person's personality which is formed from the strength of the human being, (6) Passion / drive that affects 
one's motive for actions, (7) Heredity, a basic human psychological and physiological ability factor passed down by parents. (Mohammad Muchlis, 2007).

The human potential given by Allah SWT is in the form of sight, hearing, and heart, all of which have a relationship where hearing functions to maintain the knowledge that has been found from the results of learning and learning, vision functions to develop knowledge and add research results by conducting further studies. The heart is in charge of cleansing knowledge of all bad qualities. The last one relates to the theory of learning and learning in the aspects of faith and morals.

Based on the foregoing, it can be explained that in fact no single human being is born with knowledge attached to him, but humans can obtain it through a process by utilizing the inherent potentials, namely hearing, sight, and heart. The hope is that humans are able to maximize all their potential to become humans with character and dignity. One way to produce human dignity and character is of course through a structured learning process through educational programs.

\section{CONCLUSION}

The human potential given by Allah SWT is in the form of sight, hearing, and heart, all of which have a relationship where hearing functions to maintain the knowledge that has been found from learning and learning outcomes, vision functions to develop knowledge and add research results by conducting further studies. The heart is in charge of cleansing knowledge of all bad qualities.

\section{References}

Abdul Basyit. (2017). Memahami Fitrah Manusia Dan Implikasinya Dalam Pendidikan Islam. Rausyan Fikr, 13(1), 1340-1350.

Abdullah, D. (2017). Konsep Manusia Dalam Al-Qur'an (Telaah Kritis tentang Makna dan Eksistensi). Al Daulah : Jurnal Hukum Pidana dan Ketatanegaraan, 6(2), 331-344. https://doi.org/10.24252/ad.v6i2.4886

Akhirin. (2015). Pengembangan Potensi Anak Perspektif Pendidikan Islam. Jurnal Tarbawi, 12(2).

Amir, D. (2012). Konsep Manusia Dalam Sistem Pendidikan Islam. Al-Ta lim, 19(3), 188. https://doi.org/10.15548/jt.v19i3.52

Fhauziah, H. (2015). Hubungan Konsep Manusia Dengan Konsep Pendidikan Islam Menurut Haji Abdul Malik Karim Amrullah. Fakultas IImu Tarbiyah dan Keguruan UIN Syarif Hidayatullah.

Harahap, M., \& Siregar, L. M. (2017). Konsep Pendidikan Islam Dalam Membentuk Manusia Paripurna. Jurnal Pendidikan Agama Islam Al-Thariqah, 2(2), 148-163. https://doi.org/10.25299/althariqah.2017.vol2(2).1040

Hartono. (2013). Konsep Belajar dan pembelajaran Menurut QS. An-Nahl:78. Insania, 16(40), 311-326. Imam Faqih. (2005). Konsepsi Potensi Manusia. 50-68.

Katsir, I. (2004). Tafsir Ibnu Katsir Jilid 5. Pustaka Imam Syafi'i.

Kosim, N., \& Syah, L. (2016). Potensi dasar manusia menurut ibnu taimiyah dan implikasinya dalam pendidikan islam skripsi. Qathrunâ, 3(1), 63-97.

M. Quraish Shihab. (2005). Tafsir Al-Mishbah (Pesan, Kesan dan Keserasian Al-Qur'an) (Tiga). Lentera Hati.

Mohammad Muchlis, S. (2007). Fitrah; Konsep Dan Pengembangannya Dalam Pendidikan Islam. Tadrîs, 2(2), 236-249.

Mualimin. (2017). Konsep Fitrah Manusia dan Implikasinya Dalam Pendidikan Islam. Jurnal Pendidikan Islam Al-Tadzkiyyah, 8(II), 249-266. 
Permatasari, E. (2009). Potensi Manusia dalam Surah al Baqarah ayat 30-39 dan Implikasinya dalam Pendidikan Islam. Universitas Islam Negeri Sunan Kalijaga Yogyakarta.

Rahardjo, D. (2016). Potensi Belajar Dalam Al-Qur'an ( Telaah Surah An-Nahl: 78 ). Jurnal Edukasi Islami, 05, 1411-1429.

Rahmawati. (2008). Potensi Dasar Manusia Menurut Ibnu Taimiyah dan Implikasinya Dalam Pendidikan Islam. Dalam Qathrunâ (Vol. 3, Nomor 1).

Siregar, R. L. (2016). Al- Af ' idah dan Qulub serta Kaitannya dengan Pendidikan. jurnal Al-Hikmah, 13(1), 100-109.

Syamsul Rizal. (2017). Melacak Terminologi Manusia Dalam Al-Qur'an. Jurnal At-Tibyan, 2(2), 87. https://doi.org/10.1017/CB09781107415324.004 